\title{
Ricoeur and the Symbolic Roots of Religious Experience
}

\author{
John Starkey
}

From start to finish, Paul Ricoeur regularly defended the autonomy of his philosophical thought vis-à-vis religious belief in general and speculative theology in particular. He did acknowledge, often, that his own religious life served as a source for his philosophical thought by providing motivation to explore particular themes and questions. Still, he regularly maintained that his arguments and conclusions were constructed in accord with stated philosophical methods, such that his claims on religious themes, as on any others, would in principle be accessible to any who chose to read his texts. Of course, it is no surprise that among those who engage in the academic study of the cultural enterprise of religion, it has often been the theologians who have employed his work. And it is to their credit that the theologians who employ his ideas most typically do use him as a philosopher, whether the phenomenologist and existentialist concerned with the human will and action, the late-modern or post-modern theorist of hermeneutics, or even as simply "a philosopher of note" whose ruminations on traditional Judaeo-Christian and Greek texts and associated ultimate questions offer potential insight for the theologians' constructions. Still, in view of Ricoeur's own concern about the focally philosophical nature of his work, it would seem that a formally philosophical investigation of the religious aspect of his thought, as opposed to a theological one, is well warranted. ${ }^{1}$

The choice of religious experience as a topic for Ricoeur's contribution in the philosophy of religion could be, however, 
controversial. First, even if the descriptive phenomenological work of 1950's The Voluntary and the Involuntary can be seen as concerned with the experience of willing, and in that sense concerned with a rather ordinary acceptation of the word "experience," still the Husserlian phenomenologist Ricoeur is after a sort of "ideal experience," as opposed to particular individual and historical ones. ${ }^{2}$ And second, while it is true that 1960's Fallible Man has a developed sense of the role of "feeling" [French sentiment] as it arises in the heart, the thumos, in consequence of the disproportion between finite and the infinite, Ricoeur at this point still encloses this experience within the bracketing of "Transcendence" that he meant to be lifted only in his projected "poetics of the will." 3 But third, the point for many commentators might well be that even if these attempts at a sort of ideal description of pre-verbal and non-verbal aspects of experience might have been useful for the philosopher of religion at that time, this general approach to "experience" is precisely what Ricoeur more and more leaves behind as he develops his ever-increasing concern with language.

These three caveats certainly seem all the more significant in view of the fact that Ricoeur's next move is to the kind of languageand text-oriented concerns we find in 1960's The Symbolism of Evil and in 1965's Freud and Philosophy. ${ }^{4}$ In Symbolism he does affirm ancient symbols as inherent in a kind of archaic experience, or an archaic stratum of experience, but already his own focal concern is with the meanings of the later myths in which the symbols occur, and so neither with the symbols' original formation nor with any presumed function in current religious experience. For that matter, in Freud and Philosophy he is so concerned with Freud's development of meta-languages to speak of how humans blend meanings and forces, how dreams and neurotic symptoms mix logos and bios, that he pays minimal attention to the clinical experiences that so concerned Freud. ${ }^{5}$ More important, by the time of The Rule of Metaphor in 1975 and of the studies from 1983 to 1985 in Time and Narrative, ${ }^{6}$ Ricoeur is so deeply caught up with linguistic analysis, hermeneutics, and narrative theory that everyday human experience not specifically mediated by written texts tends to be left behind even when the "fullness of language" is at issue. More specifically, concrete humans with ordinary religious concerns simply do not appear even to the degree they did in Symbolism of Evil. Whether the religious devotee be thought of as (a) an original oral creator of a religious symbol, albeit a creator now forever hidden from history, or (b) a later writer 


\section{JOHN STARKEY}

whose imagination has re-worked earlier oral sagas and legends containing such symbols in such fashion as to produce an entirely new narrative form, or even (c)a later reader who appropriates such symbols in such written narratives - any such actual religious person, with his or her concomitant experiences, figures only in the background. ${ }^{7}$ Ricoeur certainly never abandons his dictum that in both speech and writing "someone says something to someone about something"-but given his antipathy to Romantic concern with the genius of authors, we hear scarcely anything at all about the concrete "someones," even those of an ideal type. ${ }^{8}$

But there is more. It is not simply the disappearance of the early phenomenological description of experience and the failure of the concrete and historical religious person to put in an appearance that are likely to lead some of Ricoeur's expositors to look askance at an essay on religious experience in Ricoeur. Some-especially among those concerned with theology, and in particular, those who see all (valid) religion and theology as centered on Scripture-tend to see Ricoeur as on their side: against experience and in favor of the text. And then it must be admitted, finally, that Ricoeur certainly makes statements in which he not only passes by the subject who has religious experience but takes, or seems to take, a dim view of the category of "religious experience" as such, at least as a valid category for the philosopher. ${ }^{9}$ In a typical passage, here from a 1995 interview, Ricoeur states, 'I have vigorously resisted the word 'experience' throughout my career, out of a distrust of immediacy, effusiveness, intuitionism: I have always favoured, on the contrary, the mediation of language and scripture; ...."10 That stricture, and others like it, has led many to focus almost exclusively on the formally textual, hermeneutic, and indeed epistemological aspects of his thought. ${ }^{11}$

But is the writing and interpreting of texts all there is, in Ricoeur's views? No_-and hence the goal of this essay: to argue that while Ricoeur does attack various inadequate models of religious experience, he does acknowledge the phenomenon and maintains both explicit and implicit positions on various questions with respect to it. Take the following statement-from, significantly, the very same interview. Ricoeur has been asked, "Do you think that there are particular circumstances in which it would be possible to perceive something of what lies beyond the language within which you say you live?" $\mathrm{He}$ replies by pointing to end-of-life experiences among those suffering 
from AIDS or cancer, and states,

I have had the impression that one can observe, at that moment, that the appeal to resources of courage and trust comes from farther than this or that language; it is here that today I would reintroduce the idea of experience ... [T] here is perhaps a moment ... when, confronting death, the veils of this language, its limitations and codifications, are erased in order to let something fundamental [emphasis in the original] express itself, which perhaps then, effectively belongs to the order of experience ... I think, however, that these experiences are rare, perhaps similar to those lived by the mystics. I have no experience in this sense. I have instead been attentive to the interpretation of texts, to the ethical invitation, even if, beyond the duty and even the desire to "live well," I readily confess that there is a call to love that comes from farther and from higher. ${ }^{12}$

This text, however its content may be interpreted in detail, makes clear that whether Ricoeur's "reintroduction" here of the concept of religious experience should be interpreted as a retraction of earlier statements, or a qualification of them, or most likely simply a discovery of a proper use of a term in a way that he now has come to believe can transcend the earlier strictures, Ricoeur can use the term "experience," and does characterize one type of experience as that in which the "veils of this language ... are erased." True, the content of this quote is difficult to interpret, in view of all we know about Ricoeur. Why put himself in the situation of at least apparently moving away from the very position he had so vigorously and ever more powerfully argued for, the position most interpreters take as their focus, the position that the linguistic element is inherent in human experience? That is the question I wish to pose, as I examine and in part seek to reverse, Ricoeur's "weighted focus" on the linguistic over the pre-linguistic in religious experience. ${ }^{13}$

\section{'Religious Experience [of God or ...]': In Lieu of a Definition}

We could try to proceed in a standard manner: to reproduce or at least rationally reconstruct Ricoeur's definitions for the terms "religious" and "experience," then for the putative referent(s) of such experience, then for the three in combination. But as the commentators generally note, Ricoeur's usual procedure is certainly not to provide us 


\section{JOHN STARKEY}

with stipulative definitions and then defend them, but rather to comment on others' work, initially remaining within the ambit of their definitions and methods, then gradually altering them, often in subtle ways. Here the plurality of his sources and his own use of multiple avenues of approach to all three terms is especially problematic insofar as he is nowhere focally concerned with presenting a theory of religious experience. Poetically put, we face an apparent road-block with respect to defining religion, a morass with respect to the uses of the term experience, only to find ourselves on a road that does notlead to Romeor to any other specifiable destination.

That is, so far as the initial apparent road-block with regard to "religion" is concerned, we would have to face first Ricoeur's general Protestant preference for faith over religion, second his more specific Reformed distrust of the sacramental or mystical aspects of religion, and third his postmodern concern for particularity, which leads him to deny that there is any such thing as a phenomenology of religion in general. ${ }^{14}$ We might try to get past this first problem by appeal to faith as a human act, ${ }^{15}$ but then would need to admit that the second problem would not only remain, but would do so in what would now be an exacerbated form. That is, though Ricoeur does distrust the sacramental, he still sees it in a tensive relation to the prophetic, a tension inhering in the act of faith itself. ${ }^{16}$ And even if we could define religious faith as an act with sufficient clarity, we would have to face the ensuing third problem in a likewise intensified form, since it is precisely the complexity just mentioned that provides the rationale for the insistence on the particularity of specific religious texts to begin with, and so of their referent(s) - a particularity which seems to render nugatory any attempt at a single coherent philosophy of religion.

So far as the morass with respect to "experience" is concerned, the mud may lie deep. Recall the variety of Ricoeur's dialogue partners. Experience meant one thing for existentialists Marcel and Jaspersespecially in view of the importance of lived experience for Marcel and limit-experience for Jaspers. Then we would need to connect Jaspers' view to Kant's, seeing Jaspers' vision of the cipher as perhaps already entailed in Kant's doctrine of the thing-in-itself (Ding an sich), or at least in Jaspers' development of that concept. This line would undoubtedly lead us in the direction of Ricoeur's own distinctive development of Kant's notion of a limit-idea. We might then pursue an alternate development of Kant in terms of what experience meant for Husserl, or rather in the series of positions taken by Husserl, 
depending on which set of brackets was or was not in play-not to mention Ricoeur's own hermeneutic alterations of Husserl's procedures. ${ }^{17}$ Then, of course, experience meant something else entirely for Freud, who might refer to the experience of the dream, the experience of the production of the censored verbal dream-text, or the experience of sharing (or not sharing) that already censored text with the therapist. And so on.

Finally, so far as combining Ricoeur's ways of using the terms into a single phrase_ — "religious experience" — is concerned, along with tying that phrase to a referent, we have to deal with the fact that Ricoeur, like Hegel, is more convinced of the value of the historical variations on the theme than in assuming a concept capable at the outset of any stable definition. The most likely case is that Ricoeur may "fail" to give a definition of even so central a term as "religious experience" because Ricoeur implicitly believes that what is in question can be defined only in, precisely, Hegelian fashion, i.e. by a "succession of figures," with the truth being found in the dialectic rather than any individual moment thereof. One could even speculate that a reason for the parallels between the two thinker's procedures lies in a conviction that it is precisely the nature of the "referent" of such experience that renders the succession of figures both inevitable and interminable. ${ }^{18}$

Since it seems to me that all the preceding, from Ricoeur's diffidence about importing religious convictions into philosophy, to the linguistic turn, to the complexity of all the terms involved, provides at least a highly plausible set of reasons as to why Ricoeur himself never defined religious experience, and in view of the enormous difficulty of working through the tasks just outlined, I seek right now something less clear but perhaps richer than any definition. That is, I am seeking a paradigm capable of integrating the themes so far mentioned, and to take that paradigm from Ricoeur's own "pilgrim's progress"- albeit the pilgrimage of the philosopher of religion, not the religious believer. I cannot provide Ricoeur's definition of "religious experience" but what I can do is illuminate elements that would contribute to a paradigm, partially delimiting that paradigm by engaging the somewhat manageable task of showing some of the views that Ricoeur's various publications definitely exclude.

But before proceeding any further, I need to lay down further limits of my own. One, insofar as Ricoeur rarely journeys outside the range of experience reflected in the Jewish and Christian Scriptures, I will not either, although that limits the utility of the resultant paradigm 


\section{JOHN STARKEY}

for constructive contemporary use. Two, I assume with Ricoeur that the modern or postmodern philosopher need not retain, and indeed should demythologize all literal interpretations of pre-critical symbols, stories, and ideas, no matter how central: e.g. that the image of God as personal means "that God has the capacity to initiate a movement of personalization," or that the resurrection of Jesus need not be interpreted as a material event, but as simply "the event founding the community arising from the disappearance of the suffering servant." 19 Third, I shall as much as possible leave aside consideration of the "object" of religious experience even as Ricoeur conceives that object. It has to be enough that Ricoeur holds that his Scriptures "name God" as the referent who ties all the scriptural symbols and stories together, yet finally escapes them all as well. ${ }^{20}$

\section{The Experiential Birth of the Symbol}

As already noted, Ricoeur certainly has no interest in identifying how a single religious symbol might function in some hypothetical early human's archaic, let alone originative religious experience, even by developing some sort of "ideal type" for such experience. Ricoeur is in effect almost wholly concerned with the other end, with that symbol's later interpretation and appropriation by a modern or postmodern reader, specifically one who encounters that symbol as already part of a religious narrative or story, a myth, and indeed as part of a narrative that has already been taken up into a specific interpretive religious tradition. Moreover, this lack of interest in a symbol taken apart from its incorporation into a narrative is not incidental, but programmaticand asking why can lead us into a helpful discussion. One route into discussion of the question is to look at the three kinds of symbols Ricoeur postulates, and to place them along a kind of continuum.

The list itself is well known. As most fully developed in Frend and Interpretation, the three types are: the "oneiric" symbols found in dreams, investigated by psychoanalysis, the "cosmic" symbols found in religious narratives, investigated by the phenomenology of religion, and the "poetic" symbols found paradigmatically in deliberately imaginative writing, investigated by literary criticism. ${ }^{21}$ In some of his earlier work, in which he speaks of primary symbols as distinct from the secondary symbols used in myth, Ricoeur does not really give a clear principle for distinguishing the three types, other than that they are investigated by different disciplines. ${ }^{22}$ Later, however, he more and 
more sees a difference between the symbol as typically more bodybound and the metaphor as more focally linguistic, and I believe that from this later perspective we can see that the three in fact did constitute a sort of continuum all along. More than that, this continuum is an experiential continuum, and an experiential continuum relevant to the philosophy of religion.

What is a symbol? Ricoeur from the outset thinks of at least some symbols - and in time of all true symbols, as distinct from metaphors - as having "roots" in the natural, physical world of space and time, whether in our own human bodies with our inherent desires, or in elements of the world around us, or both. Re-arranging the temporal order of some of his insights for the sake of the point I wish to make, we can begin with how in Frend and Philosophy Ricoeur is particularly interested in how Freud links the unconscious life of the body and of desire to the visual images of the dream and then to the verbal "dream text" produced by the patient to share with the therapist. ${ }^{23}$ Ricoeur notes Freud's own emphasis on how there are no animal instincts as such in human life, but rather only the "drives" that Freud conceptualizes as on the border between bios and logos — which is to say, Freud focuses on what animal instincts "become" in humans. But what particularly fascinates Ricoeur is how Freud says that in fact we have access to these drives only as they are brought to language, only as the dream images are converted into the dream-text. As Ricoeur never ceases to state, "This recourse to the archaic, the nocturnal, and the oneiric, ... is also an approach to the birthplace of language ...."24

In this context, I believe, we should place the oneiric symbols at one end of a continuum whose middle holds the cosmic symbols that Ricoeur, following Eliade and others, connects to religion, with literary symbols at the other end. That is, with dreams we deal with symbols whose meanings are so archaic, so shrouded by their quasibiological and fundamentally nonverbal origins, that one is hard pressed to make anything of these dream symbols at all. But with the cosmic symbols that Ricoeur thinks provide the material for phenomenology of religion, it is almost as if we can watch the symbols come to birth, or better, read them as they do so. That is, for Ricoeur, what matters precisely in the cosmic symbols that found religion is how the productive imagination of the archaic mind brings a series of correspondences to language.

For Ricoeur the human imagination is not primarily a reproductive imagination, a capacity for recalling earlier visual images. 


\section{JOHN STARKEY}

Rather, following Kant, he sees the imagination as primarily a productive imagination, an imagination that serves to create experience-in individual experience, in culture generally, and in relation to religion specifically_precisely by bringing experience to linguistic form. Someone somewhere perceives a similarity between breath and wind, and brings both together under a single word: spirit. Naturally, the word comes together with an interpretation, perhaps a magical one at the start. But that is just the point. Apart from the physical experience of the similarity of the human breath to the wind in nature, and apart from the mental experience of the similarity being brought into language in some linguistic form, humans would lack categories (whether productive or unproductive categories is not at issue yet) by which to experience the world, and so would have no human world to inhabit. And it is in this respect Ricoeur frequently addresses all the sorts of symbols presented by the phenomenologists of religion of his day: the human skull and the roof of the house, the spinal column and the pillars of the temple, etc. ${ }^{25}$

This basic insight about the functioning of the productive imagination, or set of insights about such functioning, lies behind Ricoeur's extended development of the three symbols of evil: the experience of the stain, the experience of deviation from a path or transgression of a boundary, and the experience of carrying a burden, of being weighed down. ${ }^{26}$ For Ricoeur, there actually is no real human ethical and religious evil prior to the first person to come upon these (or comparable) symbols. ${ }^{27}$ Naturally, prior to that time, persons (nascent persons? primates-on-the-way-to-being-persons?) killed, took food from others, gave false signals about likely future behavior, etc. It is just that until someone experienced guilt by avowing it - which means until someone invented the category of guilt precisely through using one or other of the symbols (for Ricoeur, presumably stain, which he sees as most archaic) to express an awareness of freedom-gone-awry, the "behavior" could not truly have been owned as an "action."

In other words, for Ricoeur imagination, freedom, and language are all, as it were, "born together." 28 A being who lacked the imagination to perceive that at some past moment there had been another and alternate course of action, or that at a present moment one could and should overcome one's denial with respect to the character of that past action, would never have "invented" the use of the images of stain or of deviation to convey the ethical conviction that one ought to have taken another possible course. Someone who lacked the insight 
to see that living with someone you have lied to can be-or needs to be-articulated as being like carrying a load of stone all day long would not have been capable of conceiving of guilt. But then, someone who lacked the actual ability to have chosen better would never have experienced the resultant situation as a polluted and burdensome situation. And so on and so forth. This is why Ricoeur so emphasizes not only the productive imagination as such but the work of that imagination. It is in actively constructing and suffering the world-i.e. experiencing it - through the work of imagination that we make it into a human world, a world of our "ownmost possibilities."

With this, we are getting near to the philosophy of religious experience, but have not yet finished with the continuum of the three types of symbols. So far Ricoeur has been speaking of what he calls "bound symbolism" — of symbols whose meaning is nearly dictated by the raw material out of which they are created, by means of which they come into being. With these the religious subject might tend to feel as if the human role were simply a passive one-more a feeling that something important is being revealed than a feeling that the subject is creating something. ${ }^{29}$ But that very distinction itself would be, for Ricoeur, the insight of a sophisticated linguist, of someone accustomed to thinking of language as produced - the insight of someone familiar with poetry. That would be the insight of someone who does not take experience, even archaic human experience, something to be merely received or suffered, but rather as something always also actively engaged and even created.

So yes, it is true that on finishing The Symbolism of Evil and Freud and Philosophy, Ricoeur more and more focused and expanded his attention to the linguistic turn of contemporary philosophy. ${ }^{30}$ But we must read this not as a turn away from experience, but rather evidence of his original and abiding Kantian-Husserlian conviction that experience is always actively produced. It is true that he paid less and less attention to the somatic and even emotional aspects of experience, more to the linguistic ones. But we should view that as fundamentally a turn to bow we concretely create experience, including for current purposes religious experience. As Ricoeur came to meditate on how metaphor lay not only at the heart of consciously poetic language but at the heart of language as such, he was engaging ever more deeply the Kantian insight that categories don't “just happen." Rather, categories are human constructions; they result from the human attempt to grasp the world in productively articulate ways, or linguistically productive 


\section{JOHN STARKEY}

ways. So long as a metaphor is fresh, prior to being put in a dictionary, that metaphor expresses a new insight into the world, expressed in a new linguistic form —or at least, it might. Whether a particular metaphor provides an insight, rather than serving as a wish-fulfilling illusion, or whether perhaps it merely proposes a guess that in the end will leave us as ignorant as we were before, is subject to the "conflict of interpretations" that constitutes everyday life among the linguistically competent—who are, ideally, poetically sensitive, ethically committed, and-if it is their fate or calling - religiously alert. ${ }^{31}$

\section{The Symbol and Religious Experience}

It may seem to some that this line of thought has overmuch "recruited" Ricoeur into the service of a philosophy of religion alien to his own, but a clear look at the history of his work would make it clear that that has not been done at all. For example, for Ricoeur it would have been quite appropriate to list religion as one of the cultural realities or activities that emerge from the cauldron in which freedom, imagination, and language blend. Indeed, so far as Ricoeur's own thought was concerned, it was to a significant degree the history of his particular religious concern about how best to articulate his experience of evil and of faith that led - along with much else - to the insights about language. So far as evil was concerned, as an existentialist he wanted to puzzle out the links between articulating the experience of suffering and the act acknowledging oneself as responsible for some though not all suffering, and to do so in a way that respected both the experience of the ordinary human and the philosophic insights into the tragicand the hopeful—-provided by such thinkers as Kant, Jaspers, Marcel, Heidegger, and Sartre. And so far as religion itself was concerned, he wanted to find out how he would be able not only to demythologize religious claims with Bultmann, and not only to demystify them with Feuerbach, Marx, Nietzsche, and Freud ${ }^{32}$ but also to retain fidelity to his religious affiliation as a Reformed Protestant and to his commitment as a religious socialist.

The task before us at this point, then, is to gather what has been said and work back to a theory of religious experience. Given what has been said about Ricoeur's ideas on the nature of the symbol, and said earlier about religion and experience as Ricoeur conceives both, is it possible to blend the three so as to present what his philosophy of religion has to say, or would have to say, about the nature of religious 
experience? More specifically, given the conviction that I stated earlier, that there is a danger in over-emphasizing the Ricoeur of the linguistic turn, the question becomes how to find in his work an adequate emphasis on "religious experience" with a reasonable connection to the sense that the phrase typically carries — at least enough to allow further development of his ideas in that direction. More than that, it would be good to make sense of Ricoeur's apparently contradictory, but at least ambivalent, comments about religious experience recorded earlier in this article. And finally, it is important to make sense of his comments in a way that will "make sense" to (ideally) any philosopher of religion, not just to one who might happen to share some of the religious convictions and conceptual formulations that animated Ricoeur's own particular religious life.

All that can be done, I believe, but only if we look at one more area that Ricoeur develops, an area implicit in much that has gone before but now requiring focal attention. Much has been said about Ricoeur's view of the role language plays in the emergence of symbols in general, and that has been appropriate. But that is not all he considered. Surely, if one thing is clearer than another to the man or woman in the street, it is that religious people, when asked how they see the world, would respond as did Shakespeare's blinded Lear on the heath, telling the Fool, "I see it feelingly." But so would Ricoeur. The question is, how will he work "feeling" into the mix with "symbol" and "language"?

First, in "Philosophy and Religious Language," even though Ricoeur strongly insists that there cannot be a phenomenology of religion in general, he does admit to a general structure of religious experience. He thinks that as religious persons apprehend the object of their belief, they are, or at least claim to be, affected by this objectwhich is to say they experience "feelings." He does not think that all religious persons in all religions have the same feelings, but it is indeed feeling that is the common denominator. Indeed, in that article, and then in a series of others, he lists a variety of descriptive phrases provided by previous philosophers of religion or theologians, each arguably applicable to large numbers of religious persons in addition to the philosophers who originally coined the phrases.

Specifically, in this 1974 piece he first speaks of the feeling of "ultimate concern" as orienting the religious person in all choices, of the "feeling of absolute dependence" that underscores a divine initiative, and of the feeling of "unconditional trust" expressing a hope that 


\section{JOHN STARKEY}

finds its way in spite of contradictions. ${ }^{33}$ In another 1974 article, "Philosophic Hermeneutics and Biblical Hermeneutics," he speaks of the "ultimate care" that is the religious person's "response." ${ }^{34}$ In 1977's "Naming God" he adds "a response to a will that precedes me," and explicitly ties the list to "religious experience." 35 He further expands the list in 1992's "Experience and Language in Religious Discourse"wherein, note, the terms "language" and "discourse" are linked with "experience" and "religious," with the word "feeling" as that which ties the others together. Here he explicitly identifies the authors of the phrases (Tillich, Schleiermacher, Barth and Bultmann, ) and adds (from Rosenzweig) "the feeling of being preceded in the order of speech, love, and existence," as well as his own construction, "the feeling of belonging to an economy of the gift ...." . 36

There is more. For Ricoeur, as stated earlier, not only does the imagination give birth to the category, language, and the symbol together, but to freedom as well, and at the same time. Hence it is no surprise that for Ricoeur the various forms of "feeling" arise accompanied by corresponding "fundamental dispositions." He sees these "fundamental dispositions" as all the modalities of prayer known to religious persons, from complaints to praise, passing through supplication and demands, which is to say that each disposition is linked to its own "determinate discursive act." ${ }^{37}$ And here, again, he tries to balance the universal with the particular. He thinks that all the properly religious dispositions are responses to the religious object-but that the actual symbols that enter into the feelings and dispositions vary from culture to culture and from individual person to individual person.

Of course, it is precisely at this point that his increasing concern for language comes to the fore. As he points out in "Experience and Language in Religious Discourse," "To the linguistic mediation a cultural and a historical mediation is added, of which the former is a mere reflection," adding that "This weighty fact condemns phenomenology to run the gauntlet of a hermeneutic, and more precisely of a textual or scriptural hermeneutic." ${ }^{38}$ The point is well taken: ultimate concern no doubt takes quite a different form for a Galatian day laborer in Paul's day than for a French college professor in Ricoeur's. Still, we ought not take the point too far. While it may be true that many, most, or even all religious symbols have a profoundly linguistic and so a culturally specific character, Ricoeur has already made the claim that while this linguistic aspect of the symbols is important, perhaps crucial for the religious adherent, that aspect is never the whole of the symbol, and so never 
the whole of the experience. The symbol is rooted in bodily experience and the common physical world in which all our experience transpires. In that sense, and to that degree, experience extends beyond the linguistic. And all that being so, there is really no reason that Ricoeur's philosophy of religion cannot be employed to generate at least a broad paradigm of religious experience - at least, a paradigm setting forth a number of family resemblances among irreducibly historical, cultural, and linguistic experiences. ${ }^{39}$

\section{A Paradigm of Religious Experience}

Ricoeur's religious person is embodied and immersed in a culture, and is located in some particular cultural epoch of that culture. The believer is male or female, young or old, sanguine or melancholy, perhaps deeply religious or perhaps only mildly so. Because we do not know ahead of time which of these is true, we cannot tell ahead of time what specific qualities her or his religious experience will entail. Of course, since any religion unable to provide satisfactory experience for a sufficient number of members will presumably have died out prior to the scholar's research, we can trust that one or other of the dominant systems available will provide something for nearly everyone, although there may be a range of persons best suited for a particular religion or a particular form of it. Most religions will offer opportunity for ecstatic behavior to those whose body-based experience requires or at least encourages such; most will also offer the chance to engage in more sober activities for the others so inclined.

That said, there will be important commonalities of experience among adherents to a particular faith tradition. While the qualities and intensities of feeling will vary from person to person, there will be some ascertainable style among the community members, in particular when a community requires all members to adhere rather tightly to some linguistic code with its associated practices and strictures. One religion will tend, by the symbols and stories it presents, to lead those within its circuit to seek signs of salvation through the earthly prosperity provided by a strict but provident deity. A different religion will tend instead, by its symbols and stories, to lead to recurrent experiences of abandoning oneself to the orgiastic rites of the gods and goddesses of a fertility cult. And so on.

The symbols made available through the various Scriptures will differ from one culture to another. Likewise, believers' reading 


\section{JOHN STARKEY}

habits, which may be more literalist or more focused on free re-creation of the tradition within a range of approved alternative forms, will vary as well. Some young men and women will see visions not-very-unlike previous visions in the tradition; some older men and women will dream dreams they find surprising even if the scholar finds them typical —or the reverse. Some believers will pore over the ancient texts in which they think to find salvation, while others will angrily declare that the Scriptures have been betrayed. The bodily transformations will vary, from being slain in the Spirit to sitting quietly awaiting a message at meeting. The stories, too, will vary from accounts of the military exploits of the ancestors to stories of the healers of those who are wounded in the battles.

In short, Ricoeur's philosophy of religion, though indeed quite as textual as commonly seen-because Ricoeur is so persuaded of the central role of the social imagination in all affairs human-nonetheless has all the requisites of a plausible philosophy of religion. It is true that the account given here says next to nothing about many of the common—and valid—debates among Ricoeur's interpreters, more especially for the theologians among them. Indeed, a very large number of Ricoeur's own most pressing religious and theological concerns have been placed in brackets here. Next to nothing has been said about limit-experiences, limit-expressions, or limit-concepts. Little has been said about the object of religious experience as "other" to all that can be circumscribed by language or, for that matter, by any determinate element in experience at all. Nothing whatsoever has been said about the relationship of religious experience to time, which means that Ricoeur's own late $20^{\text {th }}$ century focus on the temporality of the believer and even of the object of belief, let alone that of religious traditions, has largely been left aside. Indeed, though reference has been made to his own writings using Jewish or Christian examples, no sustained attention has been paid to Ricoeur's cherished convictions about the deity he found to circulate among - though finally also to escape- the symbols and stories in the Jewish and Christian Scriptures to which he "listens."

Still, even in spite of these omissions - in fact, I am claiming, because of them - a number of important but sometimes neglected elements in Ricoeur's explicit and implicit philosophy of religious experience have been brought to the fore. Though the point was not highlighted, his notion of text has been shown to be more supple than might have been expected, a notion clearly involving a social imaginary 


\section{THE SYMBOLIC ROOTS OF RELIGIOUS EXPERIENCE}

as much or more than an insistence on the paramount importance of words in books. His notion of the symbol has been retrieved from being shoved into that corner of the library containing the anthropologists' studies of pre-modern peoples, or from being a mere way station to narrative, or from whatever lies on the postmodern side of narrative, and has been shown rather to remain a vital component in a notion of religious experience applicable to this era or any era.

We who spend our time in the academy are always tempted to study a major author's work for its own sake, for the pleasures of a particular sort of text, or for a particular sort of conceptual closure, or dis-closure. Ricoeur would caution, though, that the proper goal is to appropriate these ideas by employing them. In this case, his ideas have been developed in such fashion as to begin to provide a framework for philosophic dialogue about humanity's religious experiences, experiences that may differ widely with respect to linguistic articulation, but which may share in at least some cases common symbolic roots as well. But the identification of such roots requires not only the data of comparative religion, but supple theories by which to organize and indeed generate such data. In this effort, Ricoeur's work-including that "prior" to his "linguistic turn" - remains invaluable.

Oklahoma City University

\section{Notes}

${ }^{1}$ The preceding observations and claims reflect, of course, the continuing split in philosophy itself since the Enlightenment. At one end of a continuum one finds thinkers who investigate Ricoeur's philosophy of religion for their own religious ends - with of course some finding it well suited to their particular religious and theological commitments, and others inadequately supportive of theirs. At the other end lies a group of thinkers whose members largely ignore his philosophy of religion, many of whom, to paraphrase Richard Rorty, simply 'do not think about God — or religion— any more.' Of course, some are as intrigued by the "sacred" as by the "secular" Ricoeur, perhaps most especially among the ethicists, as for example William Schweiker, in his dense but insightful Mimetic Reflections: A Study in Hermeneutics, Theology, and Ethics (New York: Fordham University Press, 1990).

A classic statement of Ricoeur's insistence on having his work treated as philosophy is this: "Religious language ... places itself among the objects of philosophy, under the category of the philosophy of religion. And it is in 


\section{JOHN STARKEY}

this sense that I speak of it in my essays on the philosophy of religion of Kant, of Hegel, of Rosenzeweig, and of Levinas. My episodic discussions concerning Karl Barth, Bultmann, Tillich, and Bonhoffer are therefore to be situated entirely on the periphery of my philosophical field of investigation of religious thematics." "Reply to David Stewart," in The Philosophy of Paul Ricoeur. Library of Living Philosophers, Volume 22, ed. Lewis Edwin Hahn (Chicago and La Salle, Illinois: Open Court, 1995), 445-446.

${ }^{2}$ Paul Ricoeur, Freedom and Nature: The Voluntary and the Involuntary, trans. Erazim V. Kohák (Northwestern University Press, 1966; French original in 1950). Note that as this essay traces a line of development in Ricoeur's thought, I will refer to the date of the earliest published form of a work, usually the French version. I actually quote, however, published English translations and their titles, and the endnotes reflect the publication data for these.

${ }^{3}$ Paul Ricoeur, Fallible Man, rev. English trans. Charles Kelbley (New York: Fordham University Press, 1986; Fr. original 1960).

${ }^{4}$ Paul Ricoeur, The Symbolism of Evil, trans. E. Buchanan (reprint, Boston: Beacon Press, 1969; Fr. original 1960); Freud and Philosophy: An Essay on Interpretation, trans. Denis Savage (New Haven: Yale Univ. Press, 1970; Fr. original 1965).

${ }^{5}$ It is germane, if premature, to point out here that Ricoeur himself later regretted paying too much attention to Freud's theoretical constructions and too little to his clinical work. See Paul Ricoeur, Critique and Conviction: Conversations with Francois Azouvi and Marc de Launay, trans. Kathleen Blamey (New York: Columbia University Press, 1998), 71.

${ }^{6}$ In the main text I am simply following the major works: Paul Ricoeur, The Rule of Metaphor, trans. Robert Czerny, Kathleen McLaughlin, and John Costello (Toronto: University of Toronto Press, 1977), and Time and Narrative, 1-3, trans. Kathleen McLaughlin Blamey and David Pellauer. (Chicago: University of Chicago Press, 1984-1988; Fr. originals 1983-1985). In fairness, it should be said that the exegetical publications in a certain sense redress the balance; this point will be addressed shortly.

${ }^{7}$ I stand by the statement in the main text, but it is important at the same moment that although Ricoeur himself does not theorize as to how a particular reader might appropriate any particular religious text, and does not speak concretely of individual persons doing so, Ricoeur's omm reading of religious texts during this same period offers critics much more to work with here. Not only does he have a good deal to say about the theory of appropriation and about refiguring as the final elements in reading - his own writings on Genesis, the book of Job, the parables, and Mark's passion narrative, give us practical examples of aspects of how Ricoeur himself appropriated important Judaeo-Christian texts.

${ }^{8}$ I am not saying Ricoeur "should" have gone that route. It is just that Ricoeur, who by no means "lacks the equipment" by which to fix the 


\section{THE SYMBOLIC ROOTS OF RELIGIOUS EXPERIENCE}

traces of speakers, as demonstrated throughout all of Interpretation Theory (Fort Worth: Texas Christian University Press, 1976), nowhere shows interest in oral tradition even when dealing with a text so close to them as the passion narrative of Mark's gospel; this "neglect" is of course completely in line with his aforementioned rejection of $19^{\text {th }}$ Romantic hermeneutics and the $20^{\text {th }}$ century exegetical concern with the world that lies "behind" the text.

${ }^{9}$ A theological dispute about the nature of religious beliefs lies in the background of many such discussions, set up in part by George Lindbeck's three models in The Nature of Doctrine: Religion and Theology in a Postliberal Age (Philadelphia: Westminster Press, 1984). Lindbeck presents (i) the traditional cognitive-propositional model as one in which beliefs present claims that must be true or false; (ii) a romantic experiential-expressivist model in which beliefs express religious feeling and so need not be taken as true or false, and (iii) Lindbeck's own cultural-linguistic model, derived from Wittgenstein and Geertz, in which beliefs are akin to the grammatical rules practitioners learn and interiorize as they play a language game-to believe is to play the game.

A debate has grown up as to whether Lindbeck and an associated "Yale school" adequately acknowledge that the crucial theological issue is neither what beliefs mean nor what feelings they express and/or engender, nor even how they are acquired and employed, but whether or not the beliefs "refer" - i.e. whether they really refer to a real God (or equivalent) existing outside, and perhaps even against, a language game. Commentators debate (a) whether Ricoeur ought to be located in the experiential-expressive or the cultural-linguistic school, and (b) how that location ought to be evaluated. A helpful overview of many elements in the debate is Dan Stiver's Theology after Ricoeur: New Directions in Hermeneutical Theology (Louisville: Westminster John Knox Press, 2001), 83-87. My position is that Ricoeur ought to be seen as straddling the line between the experiential-expressive and cultural-linguistic approaches, in virtue of his conviction that language is an inherent element in human experience, but that at least some forms of language lie on the line between bios (and so feeling and expression) and logos (and so expression, language and culture), and concomitantly, that religious experience straddles a line between the nonlinguistic and the linguistic.

${ }^{10}$ Paul Ricoeur, Critique and Conviction, 139.

${ }^{11}$ Christophe Brabant's "The Truth Narrated: Ricoeur on Religious Experience," in Divinising Experience: Essays in the History of Religious Experience from Origen to Ricoeur, ed. Lieven Boeve and Laurence P. Hemming, 246-269 (Leuven: Peeters, 2004), provides an example of distrust of "experience," using the quote just given. Brabant's analysis is certainly worth study, but as his title indicates, he strongly emphasizes the narrative element.

${ }^{12}$ Ricoeur, Critique and Conviction, 145. The French, with Ricoeur's original emphasis on the term "fondemental," can be found in La Critique et 


\section{JOHN STARKEY}

la Comviction: Entretien avec Francois Azouvi et Marc de Launay (Paris: CalmannLévy, Hachette Littératures,, 1995), 220.

${ }^{13}$ The phrase "weighted focus" is Don Ihde's, presenting the thought that Ricoeur typically constructs a dialectic in which one method is favored over another, without the other being abandoned. See Don Ihde, Hermeneutic Phenomenology: The Philosophy of Paul Ricoeur (Evanston, Illinois: Northwestern University Press, 1971), 14 ff.

${ }^{14}$ The key piece for Ricoeur's rejection of a universal phenomenology of religion is "Experience and Language in Religious Discourse," in Phenomenology and the "Theological Turn": The French Debate, trans. Jeffrey L. Kosky, 127-146 (New York: Fordham University Press, 2000; original first delivered in 1992), especially 129-130.

${ }^{15}$ A key article in this regard is "Philosophy and Religious Language," first published in 1974 and now in Figuring the Sacred, ed. Mark Wallace (Minneapolis: Fortress Press, 1995). He further considered faith as an "act" in "Philosophical Hermeneutics and Biblical Hermeneutics," trans. Kathleen Blamey, in From Text to Action: Essays in Hermeneutics, II (Evanston, Illinois: Northwestern Univ. Press, 1991), 98 ff. The latter article makes the important observation that while the act faith as such is directed towards its object, the act equally entails a self-understanding on the part of the subject.

${ }^{16}$ Ricoeur has a rich vocabulary for such oppositions, reminiscent of classic Catholic-Protestant disputes: sacrament vs. word, hierophany vs. proclamation, mystical vs. prophetic, the presence of the divine in nature and fertility cult (leading to idolatry) vs. the presence of the divine in history and ethics, etc. A number are laid out in "Manifestation and Proclamation," also from 1974 and again found in Figuring the Sacred. My investigation here is largely an appeal to recall that while Ricoeur subordinates the "manifestation" pole of religion (which might involve some experience of divinity in some form) to the "proclamation" pole (seen as putting limits on all idolatrous claims), he does not reject the manifestation pole, but sees it taken up into a larger dialectic. My own tendency is to work the dialectic, but to reverse the poles.

${ }^{17}$ David Rasmussen's early explication of how Ricoeur advances a hermeneutics as the means for uncovering a Husserlian "dimension of experience" remains helpful here. See his Mythic-Symbolic Language and Philosophic Anthropology: A Constructive Interpretation of the Thought of Paul Ricoeur (The Hague: Martinus Nijhoff, 1971), $123 \mathrm{ff}$.

${ }^{18}$ I am not aware of any extended monograph on the development of Ricoeur's concepts, or even nomenclature, for "God." Certainly one very helpful work in constructing such a development would be T. M. Van Leeuwen's chapter on "Being and Language" (68-133) in his The Surplus of Meaning: Ontology and Eschatology in the Philosophy of Paul Ricoeur .(Amsterdam: Rodopi, 1981.) For that matter, his immediately preceding section on 


\section{THE SYMBOLIC ROOTS OF RELIGIOUS EXPERIENCE}

"Ontological Feeling," 62-67, is germane to the whole of this paper. An equally helpful work is the entire first part of Bernard Stevens' L'Apprentissage des Signes: Lecture de Paul Ricoeur (Dordrecht, Netherlands: Kluwer Academic Publishers, 1991), 27-96, in which he situates Ricoeur vis-à-vis "being" not only with respect to Heidegger but Wittgenstein.

${ }^{19}$ Ricoeur's statements on such issues are usually found in verbal interviews or responses, as for example these from "Reply to David Detmar" in The Pbilosophy of Paul Ricoeur. Library of Living Pbilosophers, Volume 22, ed. Lewis Edwin Hahn (Chicago and La Salle, Illinois: Open Court, 1995), 495.

${ }^{20}$ My reference is to "Naming God" in Figuring the Sacred: Religion, Narrative, and Imagination, ed. Mark I. Wallace (Minneapolis: Fortress Press, 1995); French original, 1977. Key thoughts are: "The word God says more than the word 'being' because it supposes the entire context of narratives, prophecies, laws, wisdom writings, psalms, and so on. The referent 'God' is thus intended by the convergence among all these partial discourses. ... The referent 'God' is also the index of their incompleteness. It is their common goal, which escapes each of them" (227-8). The analysis is repeated in 1992's "Experience and Language in Religious Discourse," 144.

A footnote may again help situate the background debate, this time between more traditional theologians and a group of postmodern theologians or a/theologians who, over the last 25 years or more, have been renewing an apophatic theology, at first drawing from Kierkegaard and Heidegger, more recently from Derrida and from Emmanuel Levinas. This latter group's members have held that one cannot use language of "being" at all in relation to God, with part of the debate the general postmodern issue as to whether or how language refers to anything outside itself at all. The canonical text is perhaps Mark C. Taylor's Erring: A Postmodern A/theology (Chicago: University of Chicago Press, 1984); as earlier, the issue is (a) where to locate Ricoeur and then (b) how to evaluate that location.

${ }^{21}$ The tri-partite division is common among Ricoeur's writings of the 1960s and the period just afterwards, from 1960's Symbolism of Evil through 1965's Freud and Philosophy up to the third lecture of Interpretation Theory on "Metaphor and Symbol," added to other original lectures when published in 1976, along with a number of summative and corollary articles written during the period in between.

${ }^{22}$ In addition to the books cited, one article summarizing aspects of Symbolism of Evilis particularly helpful. "Hermeneutics of Symbols and Philosophical Reflection: I." trans. Denis Savage, in The Conflict of Interpretations, edited by Don Ihde (Evanston, Illinois: Northwestern University Press, 1974, original English translation 1962; original French 1961). Ricoeur there explicitly affirms that the further one moves from symbols, the greater the loss of "depth."

${ }^{23}$ I have oversimplified to keep the presentation straightforward. Freud, as Ricoeur perfectly well knew, found matters far more complicated. 


\section{JOHN STARKEY}

Since adult dreamers already know verbal language, it can be the verbal productions within dreams that may carry primitive "imagistic" meanings, and conversely much of the visual material in a typical dream is often already preconscious rather than unconscious. As Ricoeur writes more generally about symbols: "This is precisely what makes the theory of symbols so fascinating. All the boundaries are blurred-between the things as well as between the things and ourselves." Interpretation Theory, 56. More than that, in at least some later publications Ricoeur believes that the symbols in dreams are likely to be the hackneyed images of popular culture. I myself am not yet persuaded on the latter point, and resolution might well be important for a full theory of religious experience. Yes, such images (and related feelings) can be hackneyedbut they might well be authentic in the sense of fresh to the dreamer or religious person, and may likewise tie the individual to others who resonate to the same image. For all the intricate detail on "drives" and their "representatives," see Freud and Philosophy, ch. 3, "Instinct and Idea in the 'Papers on Metapsychology,' 115-157, esp. 134 ff. For both Freud and Ricoeur — and for both psychoanalysis and the philosophy of religion - the phenomena of repression and of mystification complicate affairs enormously.

${ }^{24}$ Paul Ricoeur, "The Hermeneutics of Symbols and Philosophical Reflection: I," 287.

${ }^{25}$ This brief article cannot develop the point, but in late publications Ricoeur links his theory of mimesis to Kant's understanding of the acroamthe category which is not determined by the understanding but rather produced by the imagination in connection with individual, particular experience. Ricoeur himself develops this concept with reference to literary genres; a full theory of religious experience would develop it with reference to the common loci of religious traditions: a personal God, a heaven, that life is dukkha, etc.

${ }^{26}$ The three are first mentioned on pp. 7-8 of The Symbolism of Evil, but each subsequently receives a chapter of its own. A more economic presentation occurs in two articles in which Ricoeur summarized and extended the book, namely "The Hermeneutics of Symbols and Philosophical Reflection I \& II," originally published in French in 1961 and 1962, now in Paul Ricoeur, The Conflict of Interpretations, ed. Don Ihde, (Evanston, Illinois: Northwestern University Press, 1974), 287-334.

${ }^{27}$ The phrase "come upon" is not innocent; Ricoeur delights in ringing the changes upon the Latin invenire (and its correlates in the Romance languages), i.e. to "come upon" in its various senses of "invent," "discover," "arrive at," etc.

${ }^{28}$ John Van Den Hengel in The Home of Meaning (Washington, D.C.: University Press of America, 1982), 118, glosses the point thus: "The language of the symbol is a special type of language. The emergent language is language at its point of birth. The symbol is the moment of the creation of language, the moment when language first captures its own ground." 


\section{THE SYMBOLIC ROOTS OF RELIGIOUS EXPERIENCE}

${ }^{29}$ See footnote 25 above on the acroam.

30 The choice of verbs, "focused" and "expanded," is deliberate. Commentators can too easily write as if Ricoeur "happened" to make a "linguistic turn" sometime around 1960, perhaps in response to the general climate in philosophy at the time. In fact, the original plan for the full Philosophy of the Willwas already made clear in the text of Freedom and Nature as completed in 1948 (though not published until 1950), and even more fulsomely in the programmatic "Methods and Tasks of a Philosophy of the Will" delivered in 1951, though not published until 1952. Multiple statements there make it perfectly clear that Ricoeur from the outset intended to graft hermeneutics onto phenomenology. We ought to view him in this area as in others as not responding to philosophic fashion in philosophy, but rather as a participant with many others in the creation of such fashions.

${ }^{31}$ The series of statements just made presents in cursory fashion, obviously, claims that Ricoeur developed over the entire mid-section of his career. The books and articles already footnoted provide material on Ricoeur's own publications; I simply add here that in addition to such standard works as S. H. Clark's Paul Ricoeur (New York: Routledge, Chapman and Hall, 1990), Don Ihde's Hermeneutic Phenomenology: The Philosophy of Paul Ricoeur (Evanston, Illinois: Northwestern University Press, 1971), and John Van Den Hengel's The Home of Meaning (op. cit.), I owe much to an article by David Pellauer, one of Ricoeur's two major translators. That article is "The Symbol Gave Rise to Thought," originally published in 1987 but now in The Pbilosopby of Paul Ricoeur. Library of Living Pbilosophers, Volume 22, ed. Lewis Edwin Hahn, 99-122 (Chicago and La Salle, Illinois: Open Court, 1995). Pellauer traces the history of the concept through to the date of his writing, with some attention given to the "everyday discourse" that precedes literary work. Pellauer also has a great deal to say about Ricoeur's philosophy of religious language overall; his major article on that topic is adverted to below.

${ }^{32}$ Ricoeur typically mentions only Marx, Nietzsche, and Freud as the three "masters of suspicion," and only engages in extended writing about the first and last; he does on occasion, however, mention Feuerbach as well, as in 1964's "The Language of Faith," now found in The Philosophy of Paul Ricoeur: An Anthology of His Work, ed. Charles E. Reagan and David Stewart (Boston: Beacon Press, 1978), 237.

${ }^{33}$ Paul Ricoeur, "Philosophy and Religious Language," 47.

${ }^{34}$ Paul Ricoeur, "Philosophic Hermeneutics and Biblical Hermeneutics," 98.

${ }^{35}$ Paul Ricoeur, "Naming God," 218.

${ }^{36}$ Paul Ricoeur, "Experience and Language in Religious Discourse," pp. $127-8$.

${ }^{37}$ Although I have taken all the preceding directly from Ricoeur's articles, I first found some of it in David Pellauer's "Paul Ricoeur and the 


\section{JOHN STARKEY}

Specificity of Religious Language," Journal of Religion 61, no. 3 (1981): 264284. Pellauer there points out that Ricoeur is more concerned to differentiate religious language from other types of language than to differentiate religious experience from other types of experience, such that the emphasis for Ricoeur is on the "determinate discursive acts." Pellauer's subtleties go beyond the more summary overview I am presenting here.

${ }^{38}$ Ricoeur, "Experience and Language in Religious Discourse," 130.

${ }^{39}$ Once again the article, "Experience and Language in Religious Discourse," proves important, precisely because while this is the article in which Ricoeur most definitively prohibits a universal phenomenology, it is also the piece in which he most clearly lays out the path forward: through what he calls an "analogizing transfer" from one religion to another. See pages 131-2; he there contrasts what he intends from the attempt of comparative religion to work from a "placeless place." It is no surprise that Ricoeur finds a sympathetic imagination to be the greatest aid in this "analogizing transfer" from the categories of one's own tradition to those of another. 